\title{
Assessment of heavy metals and potential health risks associated with the consumption of vegetables grown on the roadside soils
}

\section{Fazal Mabood}

University of Malakand

Fazal Hadi

University of Malakand

Amin Ullah Jan

Shaheed Benazir Bhutto University Sheringal

Allah Ditta ( $\square$ allah.ditta@sbbu.edu.pk)

Shaheed Benazir Bhutto University https://orcid.org/0000-0003-1745-4757

\section{Ziaul Islam}

Shaheed Benazir Bhutto University Sheringal

\section{Manzer H. Siddiqui}

King Saud University

Hayssam M. Ali

King Saud University

\section{Ayman EL Sabagh}

Kafr el-Sheikh University: Kafrelsheikh University

\section{Research Article}

Keywords: Rumex dentatus, Trachyspermum ammi, Spinacia oleracea, Allium cepa, lead, nickel

Posted Date: November 29th, 2021

DOI: https://doi.org/10.21203/rs.3.rs-1115842/v1

License: (1) (1) This work is licensed under a Creative Commons Attribution 4.0 International License. Read Full License 


\section{Abstract}

Vegetables cultivated near roads absorb toxic metals from polluted soil, which enter into the human body through the food chain and cause serious health problems to humans. The present study investigated the contamination level of lead $(\mathrm{Pb})$ and nickel $(\mathrm{Ni})$ in soils and vegetables grown along the roadside of District Swat, Pakistan, and the health risks associated with the consumption of the tested vegetables have been investigated. The plant samples were collected from the cultivated field within a 120-meter range from the roadside. Spinacia oleracea, Allium cepa, Rumex dentatus, and Trachyspermum ammi were selected based on their importance as vegetables. In results, $\mathrm{Pb}$ concentration was higher in plants located at the distance between 0-10 m away from the roadside than the WHO permissible limit. In such plants, $\mathrm{Pb}$ concentration was higher than Ni. Rumex dentatus contained the highest concentration of $\mathrm{Pb}$ among the tested vegetables while Ni concentration was highest in Trachyspermum ammi as compared to other plants. Concentration and accumulation of both the metals decreased in soil and plants with increasing distance from the road. Similarly, target hazard quotient values noted for $\mathrm{Pb}$ and Ni were greater than unity, which shows that there is a potential risk associated with the consumption of tested vegetables near the road. Moreover, the values of target cancer risk were greater than 0.0001 , which shows that there is a risk of cancer with the consumption of tested vegetables. In conclusion, the consumption of the tested vegetables was very dangerous as it may lead to higher risks of cancer.

\section{Introduction}

Fossil fuel combustion in automobiles releases toxic heavy metals into the air, which are then deposited on the soils nearby roadsides (Suzuki et al. 2008; Bai et al. 2009). The concentration and toxicity vary in various plant species (Mehmood et al. 2021a; Murtaza et al. 2021a). High concentrations of toxic heavy metals in roadside soils have been reported in many regions across the globe (Irshad et al. 2021; Mehmood et al. 2021b; Murtaza et al. 2021b; Naveed et al. 2021a). It has been disclosed that vehicle exhaust is the main cause of the contamination of nearby roadside soils (Bai et al. 2011; Li et al. 2020). Nickel $(\mathrm{Ni})$, lead $(\mathrm{Pb})$, zinc $(\mathrm{Zn})$, and cadmium $(\mathrm{Cd})$ are toxic heavy metals that are frequently found in the soil near roadsides (Akoto et al. 2008; Mehmood et al. 2018).

Lead $(\mathrm{Pb})$ is a common pollutant present in the air, water, and soil due to the widespread use of this metal in industrial processes (Ullah et al. 2020; Kanwal et al. 2021). Combustion of petroleum products, smelting, and sewage wastes are the main sources of $\mathrm{Pb}$ pollution (Grover et al. 2010). It has been reported that Australia, the USA, and China produced 400, 516, and 1690 thousand metric tons of $\mathrm{Pb}$ in the year 2009, respectively (United State geological survey, 2009). Lead deposits on the surface of bioparticles, organic and clay particles (Sammut et al. 2010). Several biochemical factors control its adsorption in the soil such as level of inorganic and organic ligands (Shahid et al. 2011), cation exchange capacity (Vega et al. 2010), microbial and biological conditions (Arias et al. 2010), redox state (Tabelin and Igarashi, 2009), and competing cations level (Komjarova and Blust, 2009). Plants may uptake Pb through several pathways. High negative potential on the surface of plant roots is required for $\mathrm{Pb}$ 
absorption. Due to similarity with calcium (Ca), $\mathrm{Pb}$ enters into the plant mainly through channels specified for Ca transport (Wang et al. 2007).

No biological role of $\mathrm{Pb}$ has been reported until now and thus it is a non-essential element for living organisms. On contrary, it has been considered as the second most hazardous metal after arsenic (Maestri et al 2010; Mehmood et al. 2018, 2019). Besides plants, Pb also adversely affects human health. A decrease in the number of erythrocytes has been reported during $\mathrm{Pb}$ exposure because of the inhibition of enzymes (coproporphyrinogen and ferrochelatase, delta-aminolevulinic acid ALAD) needed for the synthesis of hemoglobin and red blood cell (Sipos et al. 2003; Warren et al. 2003). It has been found that $\mathrm{Pb}$ exposure increased the excretion of amino acids and glucose in urine due to its toxic effect on the proximal convoluted portion of the nephron (Loghman-Adham, 1997). Long-term Pb exposure causes kidney failure, increased blood uric acid concentration, high blood pressure, and joint infection (Alasia, 2010). The highest amounts of $\mathrm{Pb}$ (about $1 / 3$ rd of the entire body) were accumulated in the liver (Mudipalli, 2009). As $\mathrm{Pb}$ is analogous to $\mathrm{Ca}$, therefore it can cross the blood-brain barrier easily where it can replace and activate calcium-mediated activities, which disturb brain physiology and development (Sanders et al. 2009). People working in the lead storage industry, show disorders of the male gonads (testes), reduced testosterone production, and low sperm count in semen (Queiroz and Waissmann 2006). Threshold limit of $\mathrm{Pb}$ that can cause reproductive abnormalities is about $40 \mu \mathrm{g} \mathrm{dL}^{-1}$ (Quintanilla-Vega et al. 2000). Lead affects the menstrual cycle, reduces the duration of pregnancy, and causes abnormal birth (Han et al. 2000).

$\mathrm{Ni}$ is the 22nd most abundant element found in the earth's crust, occurring mostly in rocks as a free metal or bonded with iron metal. $\mathrm{Ni}$ is a hard, ductile, and silvery-white metal (Mcllveen and Negusanti, 1994). Concentrations of $\mathrm{Ni}$ in soil and drinking waters are lower than 100 and 0.005 ppm, respectively (Naveed et al. 2020, 2021b). Anthropogenic sources of Ni pollution include vehicular emissions, fossil fuel burning, mining, smelting, municipal and industrial wastes (Alloway, 1995). Ni concentrations may reach up to $26000 \mathrm{ppm}$ in contaminated soils (Alloway, 1995).

$\mathrm{Ni}$ is absorbed by plants mainly through the root system via both passive and active transport (Seregin, 2006). The ratio of $\mathrm{Ni}$ uptake between active and passive transport changes with plant species, $\mathrm{Ni}$ form, and Ni concentration in the soil (Dan et al. 2002; Naveed et al. 2020). Moreover, soluble compounds of $\mathrm{Ni}$ might also be absorbed through the $\mathrm{Mg}$ ion transport system, due to the similar charge/size ratio of the two metal ions (Oller et al. 1997). However, its concentration in most of the plant species is extremely low i.e. 0.05-10 ppm (Nieminen et al. 2007). Extremely high concentrations of Ni have made some farmland soils unsuitable for growing crops, vegetables, and fruits (Naveed et al. 2021).

In humans, $\mathrm{Ni}$ is an abundant metal commonly responsible for skin allergies and is one of the greatest causes of allergic contact dermatitis, as revealed by positive dermal patch tests (Cavani, 2005). Ni is a carcinogenic element in several animal species but the basic mechanisms behind are still unknown (Chang, 1996). Ni can act as a tumor inducer by inhibiting natural killer cell activity (Costa and Klein, 
1999). Another possible way by which $\mathrm{Ni}$ induces cell death and/or damage is through lipid peroxidation (Misra et al. 1990; Chen et al. 1998; Janicka and Cempel, 2001).

Based on the above discussion, it has been found that both $\mathrm{Pb}$ and Ni cause toxic effects on plants as well as humans. The increasing needs of the human population for food have resulted in intensive farming, even near the roadsides. In addition, there is an increasing trend regarding the production of vegetables along the roadside near urban areas. Therefore, it is necessary to evaluate the contamination level of heavy metals especially $\mathrm{Pb}$ and $\mathrm{Ni}$ in soils as well as plants growing along the roadsides, as it would help in exploring the contamination level of these metals in those soils and plants and to calculate health risks associated with the consumption of these edible plants growing along the roadside. Moreover, it would also help in identifying the safe distance for the production of different crop plants along the roadside. Up to our knowledge, no study has focused on this aspect of the present research work conducted. Based on these hypotheses, the present study was conducted to investigate the contamination level of $\mathrm{Pb}$ and $\mathrm{Ni}$ in soils and plants that grew along the roadside of Bara Bandai, Ningolai, and Ghalegay, District Swat, Khyber Pakhtunkhwa. Moreover, different parameters related to the health risks associated with the consumption of the tested vegetables have been investigated.

\section{Materials And Methods}

\section{Study area}

The present study was conducted to investigate the contamination level of $\mathrm{Pb}$ and $\mathrm{Ni}$ in soils and plants that grew along the roadside of Bara Bandai, Ningolai and Ghalegay, District Swat, Khyber Pakhtunkhwa. Plants and soil samples were collected from the cultivated fields near the roadside at Bara Bandai, Ningolai, and Ghalegay.

\section{Collection of soil and plant samples}

Plant samples were collected from the cultivated field within a 120-meter range from the roadside. Collection of plants was made in four groups based on their distance range from road i.e. group-I (0-10 m distance), group-II (10-40 m distance), group-III (40-80 m distance), and group-IV (80-120 m distance). Five replicates were taken for each plant at each range. Similarly, five soils samples were randomly collected from each range. Plants (Spinacia oleracea, Allium cepa, Rumex dentatus, and Trachyspermum ammi) were selected for the present investigation based on their importance as vegetables.

\section{Acid digestion of soil and plant samples}

Collected soil samples were ground and sieved $(2 \mathrm{~mm})$ to remove large particles. Parameters such as electrical conductivity and $\mathrm{pH}$ were calculated using a pH meter (Model CON.3173) and electrical conductivity meter (Model CON 5). For acid digestion, $0.25 \mathrm{~g}$ from each soil sample was added in acid solution ( $5 \mathrm{ml}$ nitric acid and $1 \mathrm{ml}$ sulfuric acid) in digestion tubes and placed overnight in a fume hood. The next day, each soil sample in acid solution was heated until a clear aliquot was obtained. The aliquot 
was filtered and the total volume was raised to $50 \mathrm{~mL}$ with distilled water. Each solution was stored in plastic bottles until analyzed for heavy metals.

Collected plant samples were cut into parts (roots, stem, and leaves) and then kept in paper envelopes. The samples were dried in the oven at $80^{\circ} \mathrm{C}$ for $48 \mathrm{~h}$ and then crushed into a powdered form using a commercial blender. Each sample was digested by the method of Allen (1974). A $0.25 \mathrm{gm}$ of the sample was taken in the conical flask and then a mixture of acids ( $5 \mathrm{ml}$ nitric acid and $1 \mathrm{ml}$ sulfuric acid) was added to it and boiled on a hotplate until digested completely. After digestion, each sample was cooled, filtered and then the final volume is raised to $50 \mathrm{~mL}$ by adding distilled water. The solutions were stored in plastic bottles for metal analysis. The metal analysis of both soil and plants samples was carried out at Central Resource Laboratory, Peshawar using atomic absorption spectrophotometer (AA2407, USA).

\section{Health risk assessment}

\section{Bioconcentration factor (BCF)}

It is the ratio of heavy metal concentration in the edible part of the plant to heavy metal concentration in a soil sample (Sharma et al. 2018). BCF was calculated using the following formula:

$$
B C F=\frac{C_{\text {plant }}}{C_{\text {soil }}}
$$

where $\mathrm{C}_{\text {plant }}$ is heavy metal content in the edible part of plant and $\mathrm{C}_{\text {soil }}$ is heavy metal content in respective soil. The value of BCF greater than 1 indicates that the plant is a potential accumulator of the metal being considered for analysis.

\section{Estimated daily intake (EDI)}

The estimated daily intake of the metals was determined based on their mean concentration in each plant sample and the estimated daily consumption of the vegetables in grams. The EDI value of each metal of interest was determined by the formula used by Chen et al. (2011) with slight modification as presented in the following equation:

$$
E D I=\frac{E_{f} \times E_{d} \times F_{I R} \times C_{m} \times C_{f}}{B_{w} \times T_{A}} \times 0.001
$$

where $E_{f}$ is exposure frequency ( 365 day/year), $E_{D}$ is the exposure duration (65 years), equivalent to an average lifetime (Woldetsadik et al. 2017), $F_{\mathbb{R}}$ is the average food (vegetable) consumption (240 $\mathrm{g} /$ person/day) which were obtained from the World Health Report $(\mathrm{WHO}, 2002)$ for low vegetable intake, $C_{M}$ is the metal concentration ( $\mathrm{mg} / \mathrm{kg}$ dry weight), $C_{f}$ is the concentration conversion factor for fresh vegetable weight to dry weight i.e. 0.085 (Harmanescu et al. 2011), $B_{W}$ is reference body weight for an 
adult, which is $70 \mathrm{~kg}$ (Woldetsadik et al. 2017), $\mathrm{T}_{\mathrm{A}}$ is the average exposure time (65yrs $\mathrm{x} 365$ days) and 0.001 is the unit conversion factor.

\section{Target hazard quotient (THQ)}

The target hazard quotient (THQ) values were estimated to assess non-carcinogenic human health risk from the consumption of vegetables contaminated by heavy metals. The THQ values were calculated using the following equation as described by Chen et al., (2011).

$$
T H Q=\frac{E D I}{R f D}
$$

Where EDI is the estimated daily metal intake of the population in $\mathrm{mg} /$ day/ $\mathrm{kg}$ body weight and RfD is the oral reference dose $(\mathrm{mg} / \mathrm{kg} /$ day) values which were 0.0035 for $\mathrm{Pb}$ and 0.02 for $\mathrm{Ni}$. If the value of THQ is < 1 , it is generally presumed to be safe for the risk of non-carcinogenic effects and if it is $>1$, it is supposed that there is a chance of non-carcinogenic effects with an increasing probability as the value upsurges (Chen et al. 2011, Antoine et al. 2017).

\section{Hazard Index (HI)}

It has been documented that the individual health risks of the analyzed heavy metals in the same vegetable are accumulative and that is expressed as hazard index (Chen et al. 2011, Antoine et al. 2017). Accordingly, the $\mathrm{HI}$ of target metals considered in this study were calculated using the following equation proposed by Antoine et al. (2017):

$$
H I=\sum_{n=1}^{i} T H Q_{n}, i=1,2,3, \ldots \ldots, n
$$

where $\mathrm{HI}$ is the sum of various metals hazards. If the $\mathrm{HI}$ value became $<1.0$, there is no apparent health impact due to the metals considered. However, an $\mathrm{HI}$ value of $>1.0$ indicates potential health impact implications. A serious chronic health impact has been suggested for $\mathrm{HI}>10.0$ (Antoine et al. 2017).

\section{Target cancer risk (TCR)}

The cancer risk posed to human health due to the ingestion of individual possibly carcinogenic metals was estimated using the following equation as described by Sharma et al. (2018). Then, the target cancer risk (TCR) resulting from heavy metals $(\mathrm{Pb}$ and $\mathrm{Ni}$ ) ingestion, which may promote carcinogenic effect depending on the exposure dose, was calculated using the following equation as described by Kamunda et al. (2016). 


$$
\begin{gathered}
C R=E D I \times C P S_{o} \\
T C R=\sum_{n=1}^{i} C R, i=1,2,3, \ldots \ldots, n
\end{gathered}
$$

where CR represents cancer risk over a lifetime by individual heavy metal ingestion, EDI is the estimated daily metal intake of the population in $\mathrm{mg} / \mathrm{day} / \mathrm{kg}$ body weight, $C P S_{O}$ is the oral cancer slope factor in (mg/kg/day)-1 and $\mathrm{n}$ is the number of heavy metals considered for cancer risk calculation. The $C P S_{O}$ values used for $\mathrm{Pb}$ and $\mathrm{Ni}$ were 0.0085 and 1.7, respectively. It has been pointed out that the slope factor converts the estimated daily intake of the metal averaged over a lifetime of the exposure directly to the incremental risk of an individual developing cancer (Kamunda et al. 2016).

\section{Statistical analysis}

The mean value of the data was calculated and then it was subjected to analysis of variance (ANOVA) and correlations between different parameters were established using statistical software SPSS 16 and MS Excel 2010.

\section{Results}

\section{Physicochemical properties of soil}

Different physicochemical properties of soils collected at different distances from the roadside are presented in Table 1. Almost all the properties varied with distance from the roadside. A decreasing trend in soil pH while an increasing trend in electrical conductivity (EC) was noted with increasing distance from the roadside. Similarly, the concentrations of lead $(\mathrm{Pb})$ and nickel $(\mathrm{Ni})$ in the soil decreased as the distance from the road increased. Concentrations of $\mathrm{Pb}$ and Ni were significantly higher at 0-10 meters from the road compared to the other distances. The highest concentrations of $\mathrm{Pb}$ and Ni recorded at 0-10 $\mathrm{m}$ from the road were 60.6 and 35.0. The concentration of $\mathrm{Pb}$ in the soil was under the normal limit (85 $\mathrm{mg} \mathrm{kg}^{-1}$ ) but that of the Ni was at the edge of the permissible limit (35 mg kg-1) by WHO, 2001. The soil was loamy in texture, which is suitable for agricultural activities purposes because it has constituents more or less the same amount required for plants growth.

\section{Lead and nickel concentrations in Rumex dentatus $L$.}

As clear from Figure 1, the highest accumulation of both $\mathrm{Pb}$ and $\mathrm{Ni}$ was in the root portion of the plants followed by stem and leaves. The Pb concentration in all the parts of Rumex dentatus $\mathrm{L}$. was above the permissible limits $\left(0.3 \mathrm{mg} \mathrm{kg}^{-1}\right)$ set by WHO/FAO, 2001 up to $80 \mathrm{~m}$ distance from the road. At 80-120 m distance, the $\mathrm{Pb}$ concentration was above the permissible limits only in the root portion of Rumex dentatus L. In the case of $\mathrm{Ni}$, the concentration was above the permissible limits in root, leaves, and stem portions of Rumex dentatus L. up to $10 \mathrm{~m}$ distance from the road. At 10-40 m away from the road, only 
the root portion accumulated $\mathrm{Ni}$ above the permissible limit. For the rest of the plants after $40-120 \mathrm{~m}$, the concentration of Ni was below the permissible limits as given by WHO, FAO, 2001.

\section{Lead and nickel concentrations in Trachyspermum ammi (L.) Sprague ex Turrill}

Nickel $(\mathrm{Ni})$ and lead $(\mathrm{Pb})$ concentration in different parts of Trachyspermum ammi (L.) Sprague ex Turrill collected at different distances from the roadside is presented in Figure 2. The red line along the horizontal axis represents the permissible limits given by World Health Organization (WHO) and Food and Agriculture Organization (FAO), 2001 for $\mathrm{Pb}\left(0.3 \mathrm{mg} \mathrm{kg}^{-1}\right)$ and $\mathrm{Ni}\left(1.5 \mathrm{mg} \mathrm{kg}^{-1}\right)$ concentration in plants to be used as food. From the data presented, as the distance from the road was increased, the bioaccumulation of $\mathrm{Pb}$ and $\mathrm{Ni}$ was decreased and vice versa. The highest accumulation of both $\mathrm{Pb}$ and $\mathrm{Ni}$ was in the root portion of the plants followed by leaves, stems, and fruit. The $\mathrm{Pb}$ concentration in all the parts of Trachyspermum ammi (L.) Sprague ex Turrill was above the permissible limits $\left(0.3 \mathrm{mg} \mathrm{kg}^{-1}\right)$ by WHO/FAO, 2001 up to $40 \mathrm{~m}$ distance from the road. At 40-80 m distance, the $\mathrm{Pb}$ concentration was above the permissible limits in the root, leaves, and stem portion of the plants while 80-120 m distance, the concentration was above the permissible limits only in the root portion of Trachyspermum ammi (L.) Sprague ex Turrill. In the case of $\mathrm{Ni}$, the concentration was above the permissible limits in the root, leaves, and stem portions of Trachyspermum ammi (L.) Sprague ex Turrill up to $40 \mathrm{~m}$ distance from the road. For the rest of the plants after 40-120 m, the concentration of $\mathrm{Ni}$ was below the permissible limits as given by WHO, FAO, 2001.

\section{Lead and nickel concentrations in Spinacia oleracea L.}

From the data presented in Figure 3, the bioaccumulation of $\mathrm{Pb}$ and $\mathrm{Ni}$ in Spinacia oleracea $\mathrm{L}$. was decreased as the distance from the road was increased and vice versa. The highest accumulation of both $\mathrm{Pb}$ and $\mathrm{Ni}$ was in the root portion followed by leaves, and stems. The $\mathrm{Pb}$ concentration in all the parts of Spinacia oleracea $\mathrm{L}$. was above the permissible limits $\left(0.3 \mathrm{mg} \mathrm{kg}^{-1}\right)$ by WHO/FAO, 2001 up to $80 \mathrm{~m}$ distance from the road. At 80-120 $\mathrm{m}$ distance, the $\mathrm{Pb}$ concentration was above the permissible limits only in the root of Spinacia oleracea $\mathrm{L}$. In the case of $\mathrm{Ni}$, a similar decreasing trend in $\mathrm{Ni}$ concentration with increasing distance was recorded in different parts of Spinacia oleracea $\mathrm{L}$. The concentration was above the permissible limits in root, leaves, and stem portions of Spinacia oleracea L. up to $10 \mathrm{~m}$ distance from the road. At 10-40 distance, the $\mathrm{Ni}$ concentration was above the permissible limit in only the root portion of the Spinacia oleracea L. For the rest of the plants after 40-120 m, the concentration of Ni was below the permissible limits as given by WHO, FAO, 2001.

\section{Lead and nickel concentrations in Allium cepa L.}

A decreasing trend with increasing distance from the roadside regarding the concentrations of $\mathrm{Ni}$ and $\mathrm{Pb}$ in different parts of Allium cepa L.was recorded (Figure 4). As clear from the data, the root portion accumulated the maximum amount of $\mathrm{Pb}$, followed by stem and leaves. In the case of $\mathrm{Ni}$, the maximum accumulation was observed in the case of the stem, followed by stem and leaves. Regarding the permissible limit of $\mathrm{Pb}$ concentration, only stem and leaves portion at 80-120 away from the roadside 
were below the permissible concentration of $\mathrm{Pb}$ while all the others were above the permissible limit of $\mathrm{Pb}$ i.e. $0.3 \mathrm{mg} \mathrm{kg}^{-1}$. In the case of $\mathrm{Ni}$, the concentration was above the permissible limit $\left(1.5 \mathrm{mg} \mathrm{kg}^{-1}\right)$ in root, stem, and leaves at 0-10 $\mathrm{m}$ away from the road while only root and stem portions had Ni concentrations above the permissible limits.

\section{Lead and nickel bioaccumulation}

As clear from the data presented in Table 2, the maximum bioaccumulation of $\mathrm{Pb}$ was recorded in Rumex dentatus L., followed by Trachyspermum ammi (L.) Sprague ex Turrill, Spinacia oleracea L., and Allium cepa $\mathrm{L}$. The shoot and root portion of Rumex dentatus $\mathrm{L}$. bioaccumulated 46.2 and $29.4 \mathrm{mg} \mathrm{kg}^{-1} \mathrm{DW}$.

\section{Correlation between $\mathrm{Ni}$ and $\mathrm{Pb}$ concentration in soil and plant samples}

A positive strong correlation $\left(\mathrm{R}^{2}=0.984\right)$ was found between $\mathrm{Ni}$ and $\mathrm{Pb}$ concentration in the soil as given in Figure 5. Similarly, a positive correlation existed between the concentration of $\mathrm{Ni}$ and $\mathrm{Pb}$ in all the studied plants as shown in Figure 6. The correlation was found to be highly significant in Trachyspermum ammi (L.) Sprague ex Turrill $\left(\mathrm{R}^{2}=0.969\right)$, Spinacia olerace $\left(\mathrm{R}^{2}=0.988\right)$, Allium cepa $\left(\mathrm{R}^{2}\right.$ $=0.959)$ and Rumex dentatus $\left(\mathrm{R}^{2}=0.906\right)$.

\section{Bioconcentration factor}

As clear from the data presented in Table 2, the bioconcentration factor (BCF) decreased with increasing distance from the road in all the species studied. The maximum value of BCF (0.7629) was observed in Rumex dentatus for the $\mathrm{Pb}$, followed by 0.4949 in Trachyspermum ammi for $\mathrm{Ni}$. The values of BCFs in Spinacia oleracea, Allium cepa, and Rumex dentatus were more for $\mathrm{Pb}$ as compared to that observed for $\mathrm{Ni}$ in the same species. The minimum BCF value (0.0312) was observed in the case of Trachyspermum ammi at 80-120 m away from the road for $\mathrm{Pb}$. A decreasing trend in BCF values was observed in all the studied species as the distance from the road was increased.

\section{Health risk assessment}

After calculation of BCF and TF, the data on heavy metals concentration in different plant species studied was analyzed regarding health risks associated. It was found that the values of estimated daily intake (EDI), target hazard quotient (THQ), hazard index (HI), cancer risk (CR), and target cancer risk (TCR) were decreased as the distance of sampling site from the road was increased. In general, the values of EDI and THQ were higher in the case of $\mathrm{Pb}$ as compared to those observed for Ni. The maximum EDI (0.0135) and THQ (3.3682) were recorded in the case of Rumex dentatus for $\mathrm{Pb}$ at 0-10 $\mathrm{m}$ away from the road. Similarly, the values of EDI and THQ in the case of Spinacia oleracea L., Trachyspermum ammi (L.) Sprague ex Turrill and Allium cepa L. were 0.0086 and 2.1507, 0.0057 and 1.4236, and 0.0052 and 1.2932 , respectively. In the case of hazard index, the maximum value (3.4445) was observed in the case of Rumex dentatus, followed by Spinacia oleracea L. (2.2466), Trachyspermum ammi (L.) Sprague ex Turrill (1.6760), and Allium cepa L. (1.3836). Moreover, the values of cancer risk (CR) regarding Ni were 
higher than that of $\mathrm{Pb}$ and these values showed a decreasing trend with incasing distance from the road. The value of $\mathrm{CR}$ for Ni was maximum (0.8413) in the case of Trachyspermum ammi (L.) Sprague ex Turrill at 0-10 $\mathrm{m}$ away from the road. A similar trend was observed in the case of target cancer risk (TCR). The maximum value of TCR (0.8413) in the case of Trachyspermum ammi (L.) Sprague ex Turrill at 0-10 $\mathrm{m}$ away from the road, followed by Trachyspermum ammi (L.) Sprague ex Turrill (0.5989) at $10-40 \mathrm{~m}$ away from the road, Spinacia oleracea L. (0.3197) at 0-10 $\mathrm{m}$ away from the road, Allium cepa L. (0.3154) at $10-40 \mathrm{~m}$ away from the road.

\section{Discussion}

Soil not only provides anchorage and support to the plants but also acts as a reservoir of different nutrients. The physicochemical characteristics of soil are very important and have a crucial role in the mobilization and distribution of toxic heavy metals. A strong correlation existed between concentrations of $\mathrm{Ni}$ and $\mathrm{Pb}$ in the soil under study, which clearly shows that their sources might be the same on roadsides i.e. traffic emission (Patel and Jain, 2021). Our study showed that $\mathrm{Pb}$ and $\mathrm{Ni}$ concentration in soil was lower than the threshold limit ( $0.3 \mathrm{ppm}$ for $\mathrm{Pb}$ and $1.50 \mathrm{ppm}$ for $\mathrm{Ni}$ ) set by World Health Organization. The concentration of $\mathrm{Pb}$ and $\mathrm{Ni}$ in soils at the road edges was significantly high $\mathrm{Pb}=60.60$ \pm 5.60 and $\mathrm{Ni}=35.00 \pm 3.24$ ) and decreased rapidly with increasing distance from the road which is in line with earlier studies (Huan et al. 2018; Li et al. 2020). Earlier, it has been found that Pb concentration on the surface of the earth naturally occurs below $50 \mathrm{mg} \mathrm{kg}^{-1}$ (Arias et al 2010). Its concentration in soil mainly changes due to anthropogenic activities. As $\mathrm{Pb}$ occurs in the petroleum products and combustion of this fuel in internal combustion engine of cars releases $\mathrm{Pb}$ into the atmosphere, which then settles down on the soil near roadsides (Sammut et al 2010). Similar is the case with nickel, which also occurs naturally in petroleum products. Nickel in soils can be found in several different forms: adsorbed or complex with organic cation surfaces or on inorganic cation exchange surfaces, inorganic crystalline minerals, water-soluble, chelated metal complexes, or free ion in soil solution. Lead does not seem to be of big concern outside urban areas but may ultimately become a problem due to decreased $\mathrm{pH}$ of soil caused by limited use of soil liming in agriculture and mobilization because of increased acid rain (Bai et al. 2011).

Plants grown in contaminated soils are exposed to the contaminants. Since plants have the natural ability to absorb dissolved substances from the soil solution and in doing so, plants also absorb toxic metals present in the soil. Comparison among lead concentrations in different plant species demonstrated significant variations with distances from roads. $\mathrm{Pb}$ concentration in plants occurred in the order of Rumex dentatus > Spinacia oleracea > Trachyspermum ammi > Allium cepa. Differences in $\mathrm{Pb}$ concentration in plants depend on several factors such as developmental stage, genetic makeup, transpiration coefficient, plant roots system in soil, plant growth rate, and nutrients needed by plants (Cenkci et al. 2010). Roots of plants absorbed the highest $\mathrm{Pb}$ concentration as compared to the other plant parts. This is because roots are more exposed to the pollutants in the soil as compared to the other parts of the plant. Many plants have been reported to retain up to $95 \%$ of $\mathrm{Pb}$ in their root portions and a 
little concentration is transported to aerial parts of a plant (Shahid et al., 2011). This restricted transport of $\mathrm{Pb}$ to the aerial parts of the plants might be due to the immobilization of $\mathrm{Pb}$ on plant cell walls by the negatively charged pectin (Arias et al. 2010). Despite this, some of the Pb moves through intercellular spaces present between plant cells and translocation with water to endodermis (Wang et al. 2007; Shahid et al. 2011). $\mathrm{Pb}$ is either stored in a plasma membrane attached with pectin, crystallized in intercellular spaces, or stored in outer root cortical cells (Yang et al. 2007). Plants collected near the roadside were more exposed to lead as compared to the plants away from roadsides. Similar results have been reported by many investigators at different locations of the world (Lone et al., 2006; Bai et al. 2011; Li et al. 2020). Nickel is an essential nutrient for plants required in very low concentrations. Nickel compounds are mainly emitted by the combustion of fossil fuel in automobiles, which results in the contamination of roadside areas with Ni particles.

The most serious problem in toxic metal pollution in agricultural soil is the absorption and accumulation of toxic metals in plants tissues. The food chain is the main route of entry of heavy metals into the human body, which accounts for about $90 \%$ of heavy metals source in the human body. Therefore, health risk assessment in the form of estimated daily intake (EDI), target hazard quotient (THQ), and hazard index ( $\mathrm{HI})$, cancer risk (CR), and target cancer risk (TCR) was done in the present study. In the present study, EDI values for $\mathrm{Pb}$ and $\mathrm{Ni}$ were below maximum tolerable daily intake i.e. 0.21 and 0.1-0.3 as reported by Chen et al. (2011) and Woldetsadik et al. (2017), respectively. In the case of THQ, values noted for $\mathrm{Pb}$ and $\mathrm{Ni}$ were greater than unity, which shows that there is potential risk associated with the consumption of all the tested vegetables up to 0-10 m away from the road. Moreover, the consumption of Rumex dentatus was not safe up to $40 \mathrm{~m}$ away from the road. All the other species were safe to use after $10 \mathrm{~m}$ away from the road except Rumex dentatus, which was safe to utilize after $40 \mathrm{~m}$ away from the road. A similar trend in $\mathrm{HI}$ was observed regarding the usage of different vegetables tested in the present study as observed in the case of THQ. In the case of TCR, all the values were greater than $1 \times 10^{-4}$, which shows that there is a risk of cancer with the consumption of all the tested vegetables. Based on these indices, it was found that the consumption of the tested vegetables was very dangerous and may lead to higher risks of cancer.

\section{Conclusions}

The results confirmed the presence of $\mathrm{Pb}$ and $\mathrm{Ni}$ in selected soils and plant samples. The concentration of $\mathrm{Pb}$ in Rumex dentatus, Trachyspermum ammi, Spinacia oleracea, and Allium cepa was above the safe limits of WHO within $80 \mathrm{~m}$ range from the road. The results demonstrated that plants collected beyond the $80 \mathrm{~m}$ range contained $\mathrm{Pb}$ concentration below the WHO safe limit. While the plant was found safe in the case of $\mathrm{Ni}$ beyond the $10 \mathrm{~m}$ range where the concentration of $\mathrm{Ni}$ in plant tissues was found below the WHO safe limit. Moreover, the consumption of studied vegetables grown along the roadside was not safe based on the values of different indices. In the case of target hazard quotient (THQ), the values noted for $\mathrm{Pb}$ and $\mathrm{Ni}$ were greater than unity, which shows that there is potential risk associated with the consumption of all the tested vegetables up to 0-10 $\mathrm{m}$ away from the road. In the case of target cancer

Page $11 / 23$ 
risk (TCR), all the values were greater than $1 \times 10^{-4}$, which shows that there is a risk of cancer from $\mathrm{Ni}$ with the consumption of vegetables to the people in the study area. Based on these results, it is highly recommended to have strict regulatory control on the cultivation of these vegetables along the roadside in the study area.

\section{Declarations}

\section{Funding}

This research did not receive any specific grant from funding agencies in the public, commercial, or notfor-profit sectors.

\section{Conflict of interest}

The authors declare that they have no competing interests.

\section{Ethics approval}

Not applicable. This manuscript does not involve researching about humans or animals.

\section{Consent to participate}

All of the authors consented to participate in the drafting of this manuscript.

\section{Consent to publish}

All of the authors consented to publish this manuscript.

\section{Authors' contribution}

All authors contributed to the study's conception and design. Fazal Mabood, Fazal Hadi, Amin Ullah Jan, Allah Ditta: Conceptualization, Methodology, Software. Fazal Mabood, Amin Ullah Jan, Allah Ditta, Ziaul Islam.: Data curation, Writing- Original draft preparation. Manzer H. Siddiqui: Visualization, Investigation. Fazal Hadi, Amin Ullah Jan, Allah Ditta: Supervision. Hayssam M. Ali, Ayman EL Sabagh: Software, Validation. Fazal Hadi, Amin Ullah Jan, Allah Ditta: Writing- Reviewing and Editing. All authors read and approved the final manuscript.

\section{Availability of data and materials}

All the data and tools/models used for this work are publicly available.

\section{References}

1. Akoto O, Ephraim JH, Darko G (2008) Heavy metal pollution in surface soils in the vicinity of abundant railway servicing workshop in Kumasi Ghana. Int J Environ Res 2(4):359-364. 
2. Alasia DD (2010) Lead nephropathy: Revisiting an overlooked cause of kidney disease. Nephrol Rev 2:e8. https://doi.org/10.4081/nr.2010.e8

3. Allen SE, Grimshaw HM, Parkinson JA, Quarmby C (1974) Chemical analysis of ecological materials. Oxford: Blackwell Scientific.

4. Alloway BJ (1995) Heavy Metal in Soils (Ed: B. J. Alloway), $2^{\text {nd }}$ ed., Blackie Academic and Professional, London, pp. 25 - 34.

5. Antoine JMR, Fung LAH, Grant CN (2017) Assessment of the potential health risks associated with the aluminum, arsenic, cadmium, and lead content in selected fruits and vegetables grown in Jamaica. Toxicol Reports 4:181-187. https://doi.org/10.1016/j.toxrep.2017.03.006

6. Arias JA, Peralta-Videa JR, Ellzey JT, Ren M, Viveros MN, Gardea-Torresdey JL (2010) Effects of Glomus deserticola inoculation on Prosopis: enhancing chromium and lead uptake and translocation as confirmed by X-ray mapping, ICP-OES, and TEM techniques. Environ Exp Bot 68(2):139-148. https://doi.org/10.1016/j.envexpbot.2009.08.009

7. Bai J, Cui B, Wang Q, Gao H, Ding Q (2009) Assessment of heavy metal contamination of roadside soils in Southwest China. Stoch Environ Res Risk Assess 23(3):341-347. https://doi.org/10.1007/s00477-008-0219-5

8. Bai J, Cui B, Wang Q, Gao H, Ding Q (2009) Assessment of heavy metal contamination of roadside soils in Southwest China. Stoch Environ Res Risk Assess 23:341-347. https://doi.org/10.1007/s00477-008-0219-5

9. Bai J, Wang Q, Zhang K, Cui B, Liu X, Huang L, Xiao R, Gao H (2011) Trace element contaminations of roadside soils from two cultivated wetlands after abandonment in a typical plateau lakeshore, China. Stoch Environ Res Risk Assess 25:91-97. https://doi.org/10.1007/s00477-010-0406-z

10. Cenkci S, Cigerci IH, Yildiz M, Özay C, Bozdag A, Terzi H (2010) Lead contamination reduces chlorophyll biosynthesis and genomic template stability in Brassica rapa L. Environ Exp Bot 67(3):467-473. https://doi.org/10.1016/j.envexpbot.2009.10.001

11. Chang LW (1996) Toxicology of Metals, Lewis Publishers: New York, pp 245-246.

12. Chen C, Qian Y, Chen Q, Li C (2011) Assessment of daily intake of toxic elements due to consumption of vegetables, fruits, meat, and seafood by inhabitants of Xiamen, China. J Food Sci 76:T181-T188. https://doi.org/10.1111/j.1750-3841.2011.02341.x

13. Chen C. H.Y., Huang Y.L., Lin T.H. (1998). Lipid peroxidation in liver of mice administrated with nickel chloride: with special reference to trace elements and antioxidants. Biol Trace Elem Res 61(2):193199. https://doi.org/10.1007/BF02784030

14. Costa M, Klein CB (1999) Nickel carcinogenesis, mutation, epigenetics, or selection. Environ Health Perspect 107(9):438-439. https://doi.org/10.1289/ehp.99107a438

15. Dan TV, Krishnaraj S, Saxena PK (2002) Cadmium and nickel uptake and accumulation in scented Geranium (Pelargonielm sp.' Frensham'). Water Air Soil Pollut 137:355 - 364. https://doi.org/10.1023/A:1015590007901 
16. Grover P, Rekhadevi P, Danadevi K, Vuyyuri S, Mahboob M, Rahman M (2010) Genotoxicity evaluation in workers occupationally exposed to lead. Int J Hyg Environ Health 213(2):99-106. https://doi.org/10.1016/j.ijheh.2010.01.005

17. Han S, Pfizenmaier DH, Garcia E, Eguez ML, Ling M, Kemp FW, Bogden JD (2000) Effects of lead exposure before pregnancy and dietary calcium during pregnancy on fetal development and lead accumulation. Environ Health Perspect 108:527-531. https://doi.org/10.1289/ehp.00108527

18. Harmanescu M, Alda L, Bordean D, Gogoasa I, Gergen I (2011) Heavy metals health risk assessment for population via consumption of vegetables grown in old mining area, a case study: Banat County, Romania. Chem Cent J 5:64. https://doi.org/10.1186/1752-153X-5-64

19. Irshad S, Xie Z, Mehmood S, Nawaz A, Ditta A, Mahmood Q (2021) Insights into conventional and recent technologies for arsenic bioremediation: A systematic review. Environ Sci Pollut Res 28(15):18870-18892. https://doi.org/10.1007/s11356-021-12487-8

20. Janicka K., Cempel M. (2001). Lipid peroxidation and selected antioxidants in rat liver after oral exposure to nickel(II) chloride. Bromatol Chem Toksykol 34:291-295.

21. Kamunda C, Mathuthu M, Madhuku M (2016) Health risk assessment of heavy metals in soils from Witwatersrand gold mining basin, South Africa. Int J Environ Res Public Health 13:663. https://doi.org/10.3390/ijerph13070663

22. Kanwal U, Ibrahim M, Abbas F, Yamin M, Jabeen F, Shahzadi A, Farooque AA, Imtiaz M, Ditta A, Ali S (2021) Phytoextraction of Lead using a Hedge Plant [Alternanthera bettzickiana (Regel) G. Nicholson]: Physiological and Bio-chemical Alterations through Bioresource Management. Sustainability 13(9):5074. https://doi.org/10.3390/su13095074

23. Komjarova I., Blust R. (2009). Effect of $\mathrm{Na}, \mathrm{Ca}$ and $\mathrm{pH}$ on simultaneous uptake of $\mathrm{Cd}, \mathrm{Cu}, \mathrm{Ni}, \mathrm{Pb}, \mathrm{and}$ $\mathrm{Zn}$ in the water flea Daphnia magna measured using stable isotopes. Aquat Toxicol 94(2):81-86. https://doi.org/10.1016/j.aquatox.2009.05.018

24. Li Y, Yuan Y, Sun C, Sun T, Liu X, Li J, Fang L, Fan Z (2020) Heavy metals in the soil of an urban industrial zone in a metropolis: risk assessment and source apportionment. Stoch Environ Res Risk Assess 34(2):435-446. https://doi.org/10.1007/s00477-020-01779-z

25. Loghman-Adham M (1997) Renal Effects of environmental and Occupational Lead Exposure. Environ Health Perspect 105(9):928-938. https://doi.org/10.1289/ehp.97105928

26. Lone MI, Raza SH, Muhammad S, Naeem MA, Khalid M (2006) Lead content in soil and wheat tissue along roads with different traffic loads in Rawalpindi district. Pak J Bot 38(4):1035-1042.

27. Maestri E, Marmiroli M, Visioli G, Marmiroli N (2010) Metal tolerance and hyperaccumulation: costs and trade-offs between traits and environment. Environ Exp Bot 68(1):1-13. https://doi.org/10.1016/j.envexpbot.2009.10.011

28. Mcllveen W. D., NegusantiJ. J. (1994). Nickel in the terrestrial environment. Sci Tot Environ 148:109138. https://doi.org/10.1016/0048-9697(94)90390-5

29. Mehmood S, Ahmed W, Rizwan M, Imtiaz M, Elnahal ASMA, Ditta A, Irshad S, Ikram M, Li W (2021a) Comparative efficacy of raw and $\mathrm{HNO}_{3}$-modified biochar derived from rice straw on vanadium 
transformation and its uptake by rice (Oryza sativa L.): Insights from photosynthesis, antioxidative response, and gene-expression profile. Environ Pollut 289:117916.

https://doi.org/10.1016/j.envpol.2021.117916

30. Mehmood S, Imtiaz M, Bashir S, Rizwan M, Irshad S, Yuvaraja G, Ikram M, Aziz O, Ditta A, Rehman SU, Shakeel Q, Mumtaz MA, Ahmed W, Mahmood S, Chen D, Tu S (2019) Leaching behavior of Pb and $\mathrm{Cd}$ and transformation of their speciation in co-contaminated soil receiving different passivators. Environ Eng Sci 36(6):749-759. https://doi.org/10.1089/ees.2018.0503

31. Mehmood S, Saeed DA, Rizwan M, Khan MN, Aziz O, Bashir S, Ibrahim M, Ditta A, Akmal M, Mumtaz MA, Ahmed W, Irshad S, Imtiaz M, Tu S, Shaheen A (2018) Impact of different amendments on biochemical responses of sesame (Sesamum Indicum L.) plants grown in lead-cadmium contaminated soil. Plant Physiol Biochem 132:345-355.

https://doi.org/10.1016/j.plaphy.2018.09.019

32. Mehmood S, Wang X, Ahmed W, Imtiaz M, Ditta A, Rizwan M, Irshad S, Bashir S, Saeed Q, Mustafa A, Li W (2021b) Removal mechanisms of slag against potentially toxic elements in soil and plants for sustainable agriculture development: A critical review. Sustainability 13(9):5255. https://doi.org/10.3390/su13095255

33. Misra M, Rodrigez RE, Kasp-Rzak KS (1990) Nickel induced lipid peroxidation in the rat: correlation with nickel effect on antioxidant defense systems. Toxicology 64(1):1-17. https://doi.org/10.1016/0300-483X(90)90095-X

34. Mudipalli A (2009) Lead hepatotoxicity and potential health effects. Review Article. National Center for Environmental Assessment-RTP Division, Office of Research and Development, U.S. EPA, North Carolina

35. Murtaza G, Ditta A, Ahmed Z, Usman M, Faheem M, Tariq A (2021a) Co-biosorption potential of Acacia nilotica bark in removing $\mathrm{Ni}$ and amino azo benzene from contaminated wastewater. Desalina Water Treat 233:261-271. https://doi.org/10.5004/dwt.2021.27514

36. Murtaza G, Ditta A, Ullah N, Usman M, Ahmed Z (2021a) Biochar for the management of nutrient impoverished and metal contaminated soils: Preparation, applications, and prospects. J Soil Sci Plant Nutrit 21:2191-2213. https://doi.org/10.1007/s42729-021-00514-z

37. Naveed M, Bukhari SS, Mustafa A, Ditta A, Alamri S, El-Esawi MA, Rafique M, Ashraf S, Siddiqui MH (2020) Mitigation of nickel toxicity and growth promotion in sesame through the application of a bacterial endophyte and zeolite in nickel contaminated soil. Int J Environ Res Public Health 17(23):8859. https://doi.org/10.3390/ijerph17238859

38. Naveed M, Ditta A, Ahmad M, Mustafa A, Ahmad Z, Conde-Cid M, Tahir S, Shah SAA, Abrar MM, Fahad S (2021b) Processed animal manure improves morpho-physiological and biochemical characteristics of Brassica napus L. under nickel and salinity stress. Environ Sci Pollut Res 28:45629-45645 https://doi.org/10.1007/s11356-021-14004-3

39. Naveed M, Tanvir B, Xiukang W, Brtnicky M, Ditta A, Kucerik J, Subhani Z, Nazir MZ, Radziemska M, Saeed Q, Mustafa A (2021a) Co-composted biochar enhances growth, physiological and 
phytostabilization efficiency of Brassica napus and reduces associated health risks under $\mathrm{Cr}$ stress. Front Plant Sci https://doi.org/10.3389/fpls.2021.775785

40. Nieminen TM, Ukonmaanaho L, Rausch N, Shotyk W (2007) Biogeochemistry of nickel and its release into the environment. In: Sigel A, Sigel H, Sigel RKO (eds) Metal ions in life sciences, vol 2. Wiley, Chichester, pp 1-30. https://doi.org/10.1002/9780470028131.ch1

41. Oller AR, Costa M, Oberd G (1997) Carcinogenicity assessment of selected nickel compounds. Toxicol Appl Pharmacol 143(1):152-166. https://doi.org/10.1006/taap.1996.8075

42. Patel DK, Jain MK. Contamination and health risk assessment of potentially harmful elements associated with roadside dust in Dhanbad India. Stoch Environ Res Risk Assess https://doi.org/10.1007/s00477-021-02061-6

43. Queiroz EK, Waissmann W (2006) Occupational exposure and effects on the male reproductive system. Cad Saude Publica 22(3):485-493. https://doi.org/10.1590/S0102-311X2006000300003

44. Quintanilla-Vega B, Hoover DJ, Bal W, Silbergeld EK, Waalkes MP, Anderson LD (2000) Lead interaction with human protamine (HP2) as a mechanism of male reproductive toxicity. Chem Res Toxicol 13(7):594-600. https://doi.org/10.1021/tx000017v

45. Sammut M, Noack Y, Rose J, Hazemann J, Proux O, DepouxZiebel M, Fiani E (2010) Speciation of Cd and $\mathrm{Pb}$ in dust emitted from sinter plant. Chemosphere 78(4):445-450. https://doi.org/10.1016/j.chemosphere.2009.10.039

46. Sanders T, Liu Y, Buchner V, Tchounwou PB (2009) Neurotoxic effects and biomarkers of lead exposure: A Review. Rev Environ Health 24(1):15.45. https://doi.org/10.1515/REVEH.2009.24.1.15

47. Seregin IV, Kozhevnikova AD (2006) Physiological role of nickel and its toxic effects on higher plants. Russ J Plant Physiol 53:257-277. https://doi.org/10.1134/S1021443706020178

48. Shahid M., Pinelli E., Pourrut B. Silvestre J., Dumat C. (2011). Lead-induced genotoxicity to Vicia faba L. roots in relation with metal cell uptake and initial speciation. Ecotoxicol Environ Saf 74(1):78-84. https://doi.org/10.1016/j.ecoenv.2010.08.037

49. Sharma S, Nagpal AK, Kaur I (2018) Heavy metal contamination in soil, food crops and associated health risks for residents of Ropar wetland, Punjab, India and its environs. Food Chem 255:15-22. https://doi.org/10.1016/j.foodchem.2018.02.037

50. Sipos P, Szentmihályi K, Fehér E, Abaza M, Szilyági M, Blázovics A (2003) Some effects of lead contamination on liver and gall bladder bile. Acta Biol Szeged 47(1-4):139-142.

51. Suzuki K, Yabuki T, Ono Y (2008) Roadside Rhododendron pulchrum leaves as bioindicators of heavy metal pollution in traffic areas of Okayama Japan. Environ Monit Assess 149:133-141. https://doi.org/10.1007/s10661-008-0188-7

52. Tabelin C, Igarashi T (2009) Mechanisms of arsenic and lead release from hydrothermally altered rock. J Hazard Mat 169(1-3):980-990. https://doi.org/10.1016/j.jhazmat.2009.04.049

53. Ullah I, Ditta A, Imtiaz M, Mehmood S, Rizwan M, Rizwan MS, Jan AU, Ahmad I (2020) Assessment of health and ecological risks of heavy metal contamination: A case study of agricultural soils in Thall, Dir-Kohistan. Environ Monit Assess 192:786. https://doi.org/10.1007/s10661-020-08722-3 
54. US Geological Survey (2009) Retrieved on 22 Dec 2012 from http://minerals.usgs.gov/minerals/pubs/commodity/lead

55. Vega F, Andrade M, Covelo E (2010) Influence of soil properties on the sorption and retention of cadmium, copper and lead, separately and together, by 20 soil horizons: comparison of linear regression and tree regression analyses. J Hazard Mat 174(1-3):522-533.

https://doi.org/10.1016/j.jhazmat.2009.09.083

56. Wang H, Shan X, Wen B, Owens G, Fang J, Zhang S (2007) Effect of indole-3-acetic acid on lead accumulation in maize (Zea mays L.) seedlings and the relevant antioxidant response. Environ Exp Bot 61(3):246-253. https://doi.org/10.1016/j.envexpbot.2007.06.004

57. Warren MJ, Cooper JB, Wood SP, Shoolingin-Jordan PM (2003) X-ray structure of a putative reaction intermediate of 5-aminolaevulinic acid dehydratase. Biochem J 373(3):733-738.

https://doi.org/10.1042/bj20030513

58. WHO (2002) The world health report 2002: reducing risks, promoting healthy life, World Health Organization, 2002. https://apps.who.int/iris/handle/10665/42510

59. Woldetsadik D, Drechsel P, Keraita B, Itanna F, Gebrekidan H (2017) Heavy metal accumulation and health risk assessment in wastewater-irrigated urban vegetable farming sites of Addis Ababa. Ethiopia. Int J Food Contam 4:9. https://doi.org/10.1186/s40550-017-0053-y

60. Yang X, Li T, Liu D, Jin X, Meng F (2007) Effect of Pb toxicity on root morphology, physiology and ultrastructure in the two ecotypes of Elsholtziaargyi. J Hazard Mat 147(3), 806-816. https://doi.org/10.1016/j.jhazmat.2007.01.117

\section{Tables}

Table 1: Physical and chemical properties of soil collected at different distances from roadside.

\begin{tabular}{llllll} 
Distance from road side $(\mathrm{m})$ & $\mathrm{pH}$ & $\mathrm{EC}\left(\mathrm{dS} \mathrm{m}^{-1}\right)$ & Texture & $\mathrm{Pb}(\mathrm{ppm})$ & $\mathrm{Ni}(\mathrm{ppm})$ \\
\hline $0-10$ & 7.01 & 5.91 & Loamy soil & $60.60 \pm 5.60^{\mathrm{a}^{\star}}$ & $35.00 \pm 3.24^{\mathrm{a}}$ \\
\hline $10-40$ & 6.70 & 5.99 & Loamy soil & $20.60 \pm 4.56^{\mathrm{b}}$ & $16.01 \pm 2.56^{\mathrm{b}}$ \\
\hline $40-80$ & 6.46 & 6.03 & Loamy soil & $13.00 \pm 3.24^{\mathrm{b}}$ & $10.33 \pm 1.25^{\mathrm{b}}$ \\
\hline $80-120$ & 6.39 & 6.04 & Loamy soil & $5.13 \pm 2.92^{\mathrm{b}}$ & $8.67 \pm 1.87^{\mathrm{b}}$
\end{tabular}

*Significant variations between values is represented by different letters.

Table 2: Bioaccumulation of $\mathrm{Pb}$ and $\mathrm{Ni}$ in root and shoot, bioconcentration factor (BCF), and translocation factor (TF) calculated for $\mathrm{Pb}$ and $\mathrm{Ni}$ concentration in different plant species sampled at different distances from the road 


\begin{tabular}{llll}
$\begin{array}{l}\text { Distance } \\
\text { from road }\end{array}$ & $\begin{array}{l}\text { Bioaccumulation of } \mathrm{Pb}(\mathrm{mg} \\
\left.\mathrm{kg}^{-1} \mathrm{DW}\right)\end{array}$ & $\begin{array}{l}\text { Bioaccumulation of } \mathrm{Ni}(\mathrm{mg} \\
\left.\mathrm{kg}^{-1} \mathrm{DW}\right)\end{array}$ & $\begin{array}{l}\text { Bioconcentration } \\
\text { factor (BCF) }\end{array}$ \\
\hline
\end{tabular}

Root Shoot Total Root Shoot Total Pb Ni

\section{Rumex dentatus $\mathrm{L}$.}

\begin{tabular}{lllllllll}
\hline $0-10 \mathrm{~m}$ & 29.4 & 46.23 & 75.63 & 2.83 & 5.24 & 8.07 & 0.7629 & 0.1497 \\
\hline $10-40 \mathrm{~m}$ & 10.13 & 14.58 & 24.71 & 1.50 & 2.61 & 4.11 & 0.7078 & 0.1630 \\
\hline $40-80 \mathrm{~m}$ & 0.93 & 1.00 & 1.93 & 0.90 & 1.42 & 2.32 & 0.0769 & 0.1375 \\
\hline $80-120 \mathrm{~m}$ & 0.30 & 0.19 & 0.49 & 0.72 & 1.00 & 1.72 & 0.0370 & 0.1153
\end{tabular}

Trachyspermum ammi (L.) Sprague ex Turrill

\begin{tabular}{lllllllll}
\hline $0-10 \mathrm{~m}$ & 24.90 & 19.54 & 44.44 & 10.25 & 17.32 & 27.57 & 0.3224 & 0.4949 \\
\hline $10-40 \mathrm{~m}$ & 12.12 & 6.54 & 18.66 & 3.17 & 5.64 & 8.81 & 0.3175 & 0.3523 \\
\hline $40-80 \mathrm{~m}$ & 2.20 & 1.04 & 3.24 & 0.90 & 1.67 & 2.57 & 0.0800 & 0.1617 \\
\hline $80-120 \mathrm{~m}$ & 0.45 & 0.16 & 0.61 & 0.56 & 1.11 & 1.67 & 0.0312 & 0.1280 \\
\hline
\end{tabular}

\section{Spinacia oleracea L.}

\begin{tabular}{lllllllll}
\hline $0-10 \mathrm{~m}$ & 18.00 & 29.52 & 47.52 & 4.24 & 6.58 & 10.82 & 0.4871 & 0.1880 \\
\hline $10-40 \mathrm{~m}$ & 4.96 & 5.76 & 10.72 & 1.67 & 2.67 & 4.34 & 0.2796 & 0.1668 \\
\hline $40-80 \mathrm{~m}$ & 1.04 & 1.05 & 2.09 & 1.00 & 1.58 & 2.58 & 0.0808 & 0.1530 \\
\hline $80-120 \mathrm{~m}$ & 0.62 & 0.45 & 1.07 & 0.64 & 1.00 & 1.64 & 0.0877 & 0.1153
\end{tabular}

\section{Allium cepa L.}

\begin{tabular}{lllllllll}
$0-10 \mathrm{~m}$ & 12.54 & 17.75 & 30.29 & 2.90 & 6.20 & 9.1 & 0.2929 & 0.1771 \\
\hline $10-40 \mathrm{~m}$ & 6.39 & 8.66 & 15.05 & 1.53 & 2.97 & 4.5 & 0.4204 & 0.1855 \\
\hline $40-80 \mathrm{~m}$ & 0.79 & 0.92 & 1.71 & 0.72 & 1.28 & 2.0 & 0.0708 & 0.1239 \\
\hline $80-120 \mathrm{~m}$ & 0.30 & 0.38 & 0.68 & 0.50 & 0.85 & 1.35 & 0.0741 & 0.0980 \\
\hline
\end{tabular}

Table 3: Estimated daily intake (EDI), target hazard quotient (THQ), and hazard index (HI), cancer risk (CR) and target cancer risk (TCR) calculated for $\mathrm{Pb}$ and $\mathrm{Ni}$ concentration in different plant species sampled at different distances from the road 
Distance Estimated daily Target Hazard Hazard Cancer risk (CR) from road intake (EDI)
$\mathrm{Pb} \quad \mathrm{Ni}$
$\mathrm{Pb} \quad \mathrm{Ni}$
(HI)
$\mathrm{Pb}$
$\mathrm{Ni}$
(TCR)

Rumex dentatus L.

\begin{tabular}{|cccccccccc}
\hline $0-10 \mathrm{~m}$ & 0.0135 & $\begin{array}{l}1.53 \mathrm{E}- \\
03\end{array}$ & $\mathbf{3 . 3 6 8 2}$ & 0.0764 & $\mathbf{3 . 4 4 4 5}$ & $1.14518 \mathrm{E}-04$ & 0.2545 & $\mathbf{0 . 2 5 4 6}$ \\
\hline $10-40 \mathrm{~m}$ & 0.0042 & $\begin{array}{l}7.61 \mathrm{E}- \\
04\end{array}$ & $\mathbf{1 . 0 6 2 3}$ & 0.0380 & $\mathbf{1 . 1 0 0 3}$ & $3.61167 \mathrm{E}-05$ & 0.2771 & $\mathbf{0 . 2 7 7 2}$ \\
\hline $40-80 \mathrm{~m}$ & 0.0003 & $\begin{array}{l}4.14 \mathrm{E}- \\
04\end{array}$ & 0.0729 & 0.0207 & 0.0935 & $2.47714 \mathrm{E}-06$ & 0.2337 & $\mathbf{0 . 2 3 3 7}$ \\
\hline $80-120 \mathrm{~m}$ & 0.0001 & $\begin{array}{l}2.91 \mathrm{E}- \\
04\end{array}$ & 0.0138 & 0.0146 & 0.0284 & $4.70657 \mathrm{E}-07$ & 0.1961 & $\mathbf{0 . 1 9 6 1}$ \\
\hline
\end{tabular}

Trachyspermum ammi (L.) Sprague ex Turrill

$\begin{array}{lllllllll}0-10 m & 0.0057 & \begin{array}{l}5.05 \mathrm{E}- \\ 03\end{array} & \mathbf{1 . 4 2 3 6} & 0.2524 & \mathbf{1 . 6 7 6 0} & 4.84034 \mathrm{E}-05 & 0.8413 & \mathbf{0 . 8 4 1 3}\end{array}$

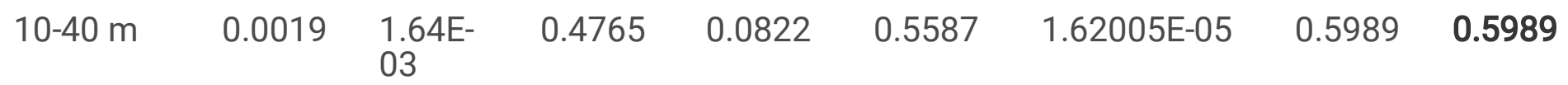
$\begin{array}{lllllllll}40-80 \mathrm{~m} & 0.0003 & \begin{array}{l}4.87 \mathrm{E}- \\ 04\end{array} & 0.0758 & 0.0243 & 0.1001 & 2.57623 \mathrm{E}-06 & 0.2748 & \mathbf{0 . 2 7 4 8}\end{array}$ $\begin{array}{lllllllll}80-120 m & 0.0000 & \begin{array}{l}3.23 \mathrm{E}- \\ 04\end{array} & 0.0117 & 0.0162 & 0.0278 & 3.96343 \mathrm{E}-07 & 0.2176 & 0.2176\end{array}$ Spinacia oleracea L.

\begin{tabular}{ccllllllll}
\hline $0-10 \mathrm{~m}$ & 0.0086 & $\begin{array}{l}1.92 \mathrm{E}- \\
03\end{array}$ & $\mathbf{2 . 1 5 0 7}$ & 0.0959 & $\mathbf{2 . 2 4 6 6}$ & $7.31253 \mathrm{E}-05$ & 0.3196 & $\mathbf{0 . 3 1 9 7}$ \\
\hline $10-40 \mathrm{~m}$ & 0.0017 & $\begin{array}{l}7.78 \mathrm{E}- \\
04\end{array}$ & 0.4197 & 0.0389 & 0.4586 & $1.42683 \mathrm{E}-05$ & 0.2835 & $\mathbf{0 . 2 8 3 5}$ \\
\hline $40-80 \mathrm{~m}$ & 0.0003 & $\begin{array}{l}4.60 \mathrm{E}- \\
04\end{array}$ & 0.0765 & 0.0230 & 0.0995 & 0.000002601 & 0.2600 & $\mathbf{0 . 2 6 0 0}$ \\
\hline $80-120 \mathrm{~m}$ & 0.0001 & $\begin{array}{l}2.91 \mathrm{E}- \\
04\end{array}$ & 0.0328 & 0.0146 & 0.0474 & $1.11471 \mathrm{E}-06$ & 0.1961 & $\mathbf{0 . 1 9 6 1}$ \\
\hline
\end{tabular}

\section{Allium cepa L.}

$\begin{array}{lllllllll}0-10 m & 0.0052 & \begin{array}{l}1.81 \mathrm{E}- \\ 03\end{array} & \mathbf{1 . 2 9 3 2} & 0.0903 & \mathbf{1 . 3 8 3 6} & 4.39693 \mathrm{E}-05 & 0.3011 & \mathbf{0 . 3 0 1 2}\end{array}$

\begin{tabular}{|c|c|}
\hline $10-40 \mathrm{~m}$ & \\
\hline
\end{tabular}

$\begin{array}{lllllllll}40-80 m & 0.0003 & \begin{array}{l}3.73 E- \\ 04\end{array} & 0.0670 & 0.0187 & 0.0857 & 2.27897 \mathrm{E}-06 & 0.2106 & 0.2107\end{array}$




\section{Figures}
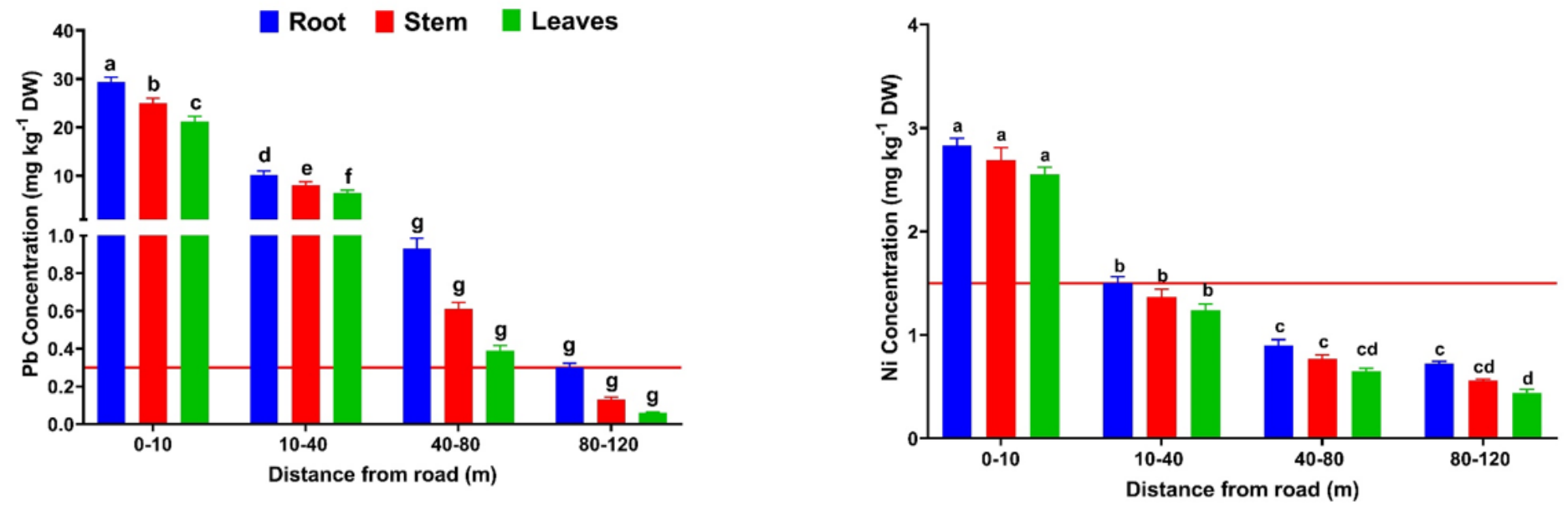

\section{Figure 1}

Lead $(\mathrm{Pb})$ and Nickel $(\mathrm{Ni})$ concentration in different part of Rumex dentatus $\mathrm{L}$. at different distances from road. Significant variations between the mean values $(n=3)$ is represented by different letters. The red line along horizontal axis represents the permissible limits given by World Health Organization and Food and Agriculture Organization, 2001 for $\mathrm{Pb}(0.3 \mathrm{mg} \mathrm{kg}-1)$ and $\mathrm{Ni}(1.5 \mathrm{mg} \mathrm{kg}-1)$ concentration in plants to be used as food
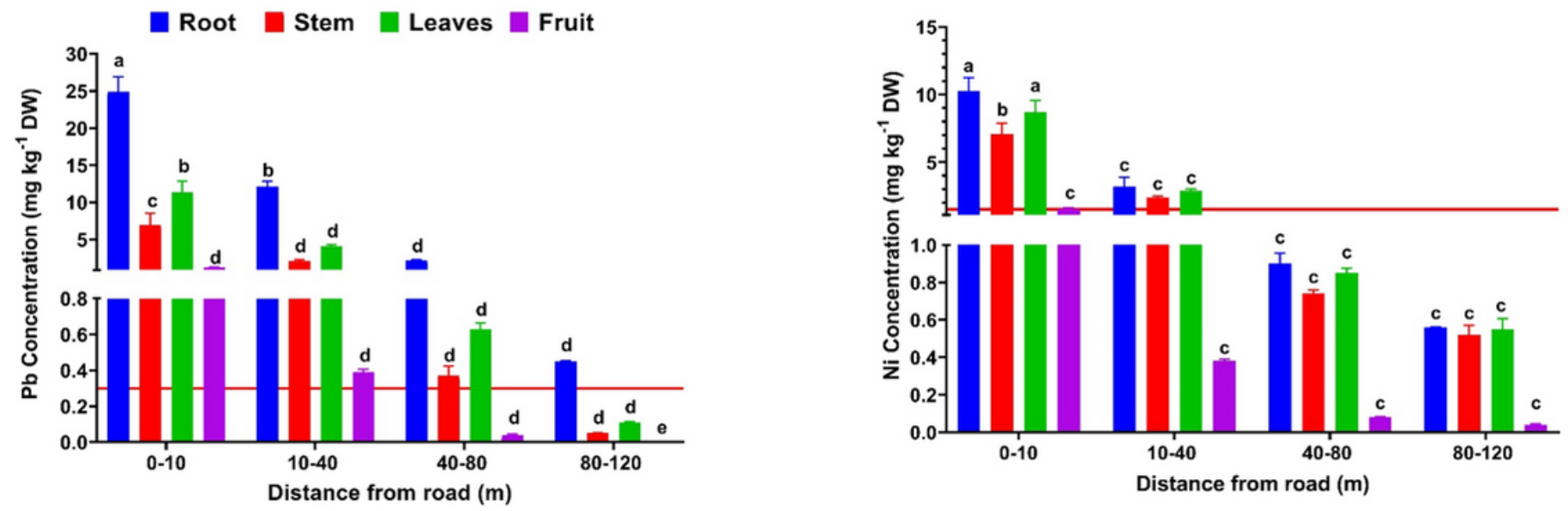

Figure 2 
Lead $(\mathrm{Pb})$ and Nickel (Ni) concentration in different part of Trachyspermum ammi (L.) Sprague ex Turrill at different distances from road. Significant variations between the mean values $(n=3)$ is represented by different letters. The red line along horizontal axis represents the permissible limits given by World Health Organization and Food and Agriculture Organization, 2001 for Pb (0.3 mg kg-1) and Ni (1.5 mg kg-1) concentration in plants to be used as food
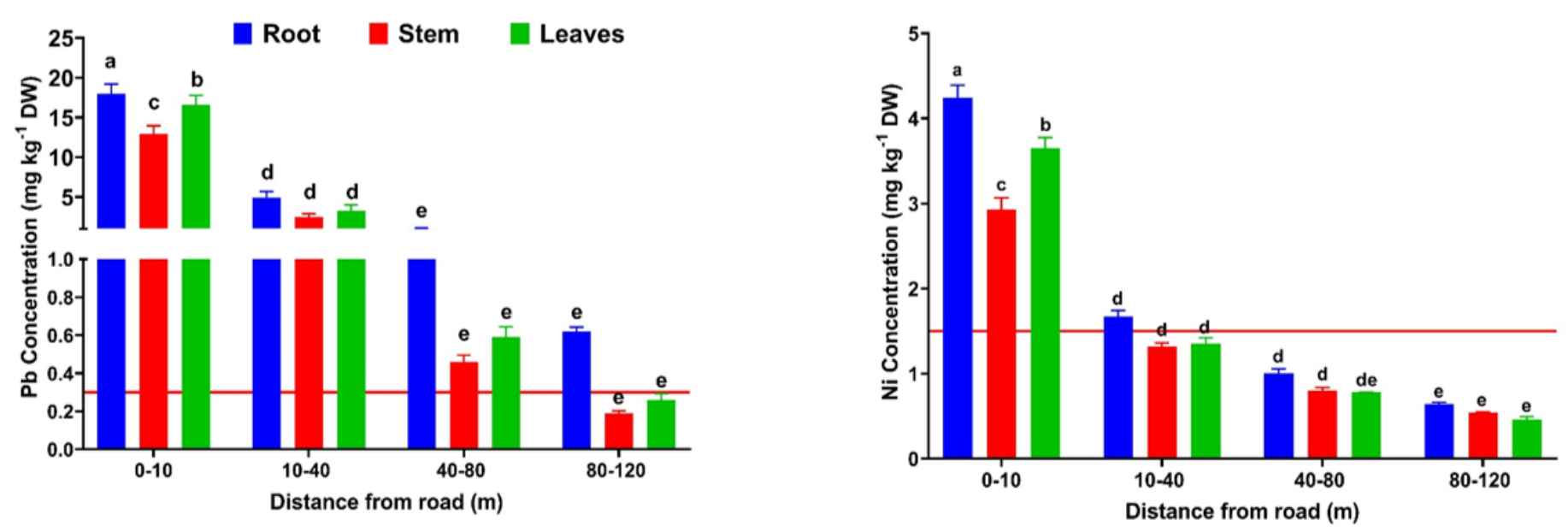

\section{Figure 3}

Lead $(\mathrm{Pb})$ and Nickel $(\mathrm{Ni})$ concentration in different part of Spinacia oleracea $\mathrm{L}$. at different distances from road. Significant variations between the mean values $(n=3)$ is represented by different letters. The red line along horizontal axis represents the permissible limits given by World Health Organization and Food and Agriculture Organization, 2001 for $\mathrm{Pb}(0.3 \mathrm{mg} \mathrm{kg}-1)$ and $\mathrm{Ni}(1.5 \mathrm{mg} \mathrm{kg}-1)$ concentration in plants to be used as food
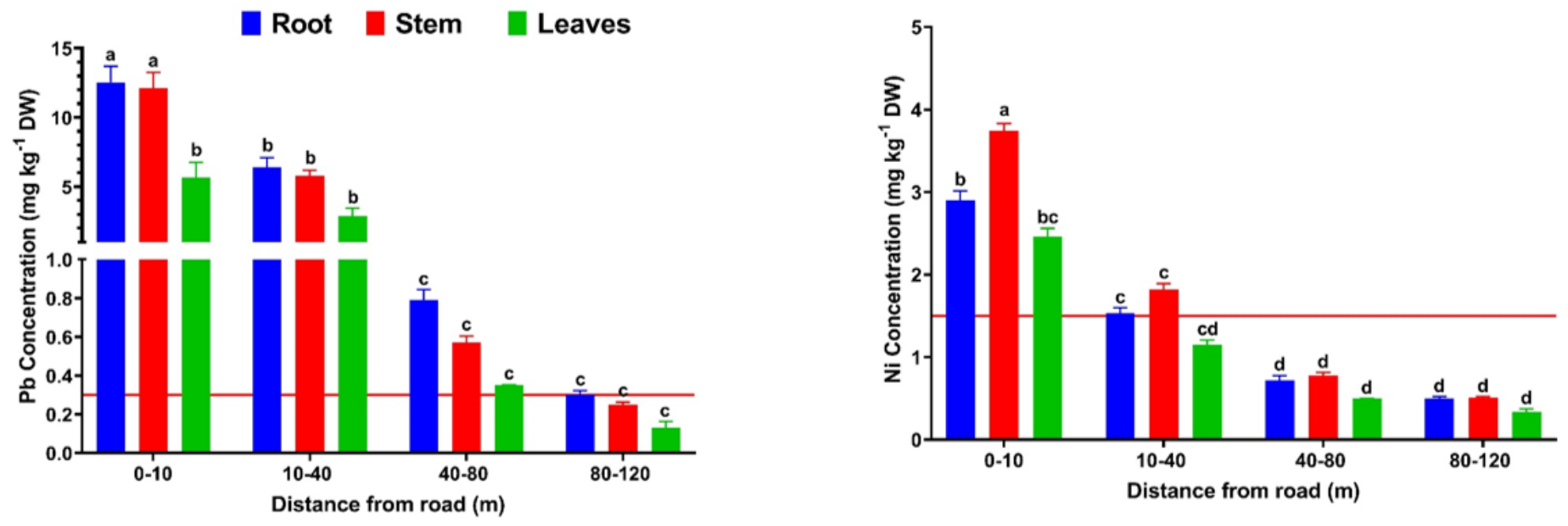

Figure 4

Lead $(\mathrm{Pb})$ and Nickel $(\mathrm{Ni})$ concentration in different part of Allium cepa L. at different distances from road. Significant variations between the mean values $(n=3)$ is represented by different letters. The red 
line along horizontal axis represents the permissible limits given by World Health Organization and Food and Agriculture Organization, 2001 for $\mathrm{Pb}(0.3 \mathrm{mg} \mathrm{kg}-1)$ and $\mathrm{Ni}(1.5 \mathrm{mg} \mathrm{kg}-1)$ concentration in plants to be used as food

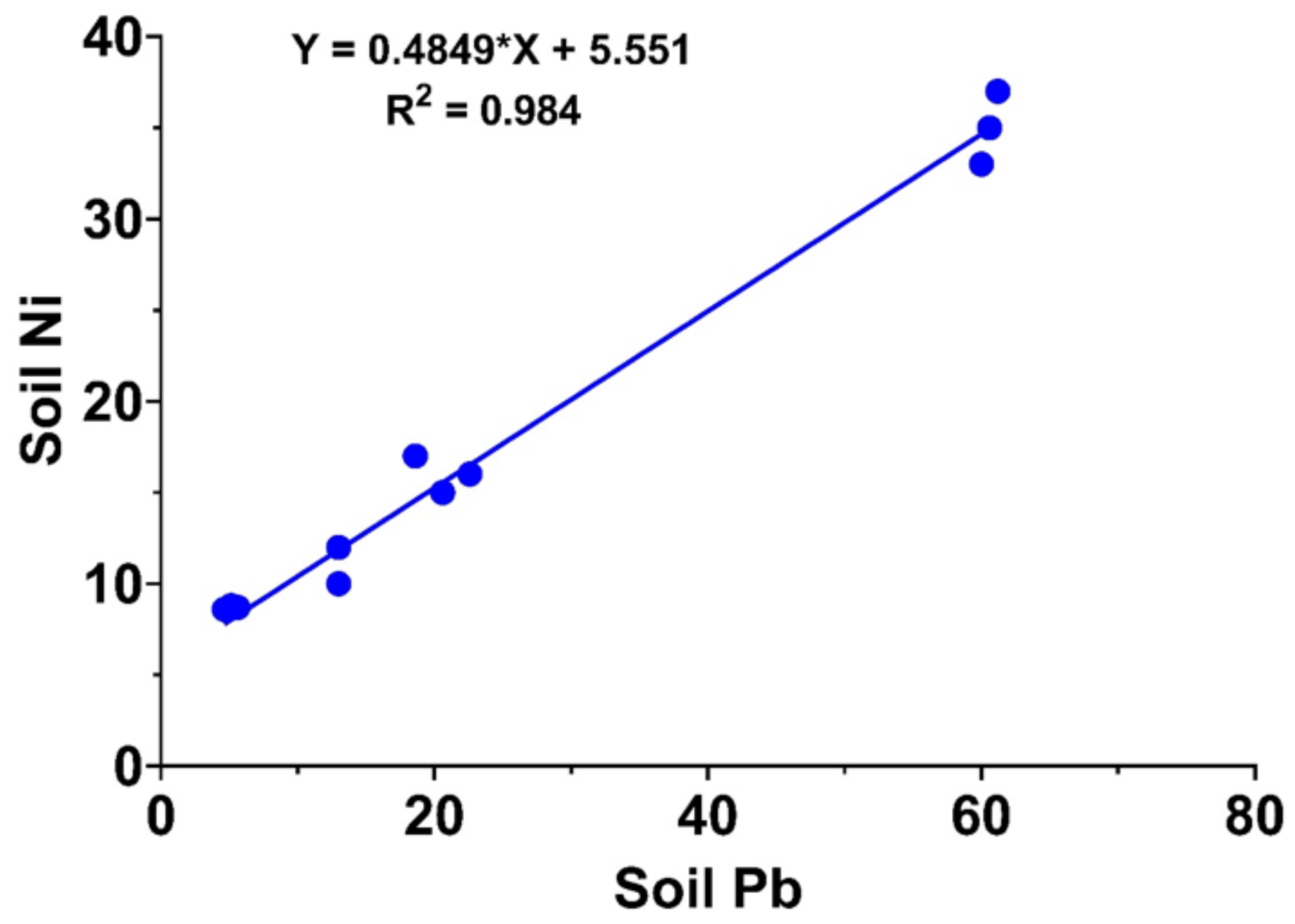

Figure 5

Correlation between $\mathrm{Pb}$ and $\mathrm{Ni}$ in soil. 

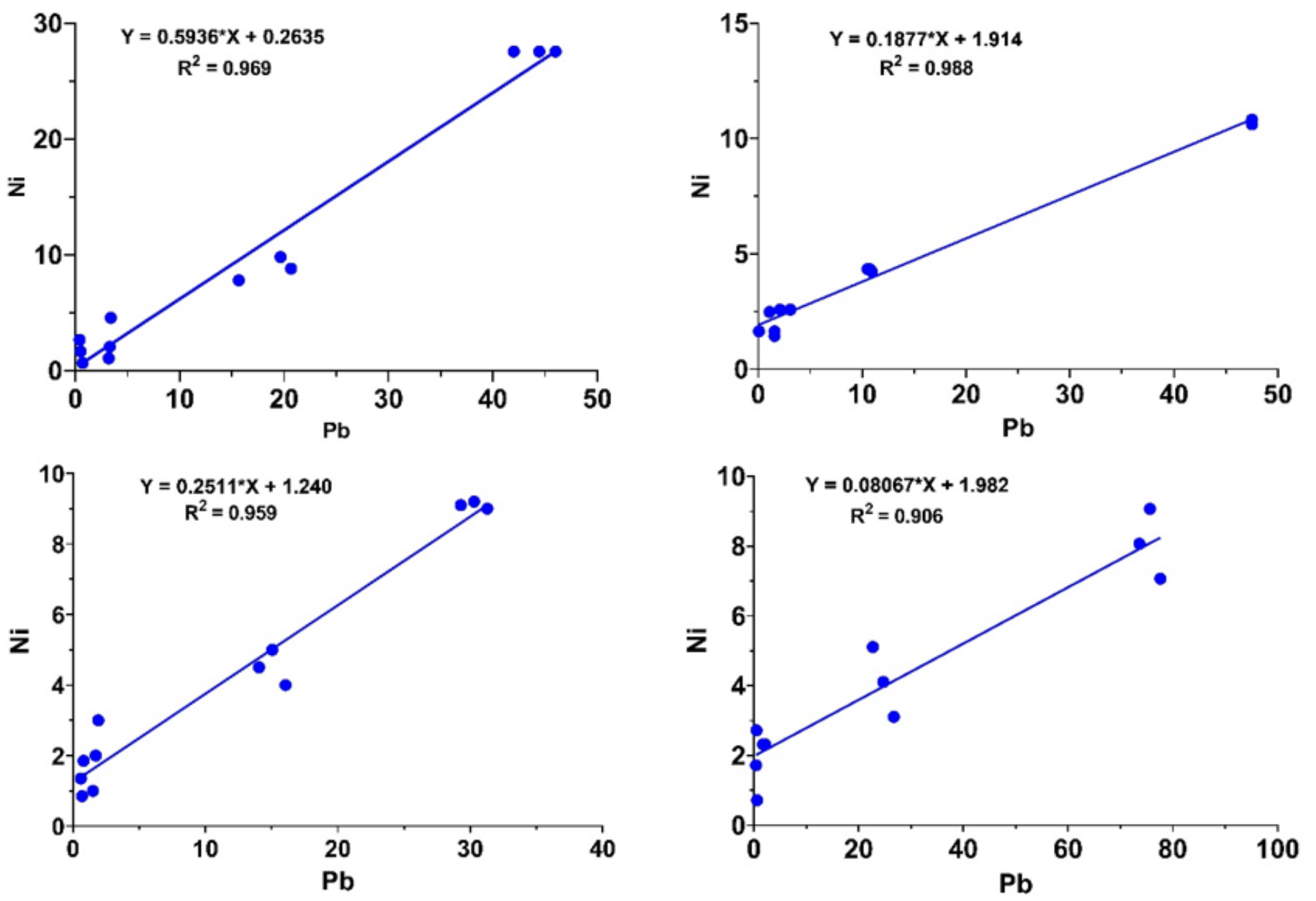

Figure 6

Correlation between $\mathrm{Pb}$ and $\mathrm{Ni}$ accumulation in Trachyspermum ammi (A), Spinacea oleracea (B), Allium cepa (C) and Rumex dentatus (D). 